Öğr. Gör. Burçe Çelik*

\title{
Rethinking the Technoscape and Contextualizing Cellular Telephony in Turkey
}

\section{Özet}

Bu makale, cep telefonunu belli toplumsal bağlamlarda oldukça popüler olan bir kültürel ürün olarak anlama arayışı içinde bir kavram geliştirme çabasındadır ve Appadurai'nin teknolojik-alan kavramını bu bağlamda tekrar düşünmeyi önermektedir. Bu çalışma teknolojik-alanın toplumsal deneyimleri içinde birbirleriyle ilişkili olan kavramlar olarak hayalin, bağın ve duygunun ne kadar önemli boyutları olduğunu vurguluyor. Teknolojik-alanı toplumsal deneyimler için hem küresel hem de yerel bir alan olarak göz önüne alırken, onun hayali ve duygusal deneyimlerine yönelik analitik bir duyarlılığın gerekliliğini iddia ediyor. Türkiye'deki 'teknolojiler' üzerine gelişen önemli dinamikler ve konular üzerine giriş niteliğinde ve tarihsel nitelikteki kimi açıklamaların ardından, teknolojik-alanın neden Türkiye'de tarihsel bir oluş hayali olarak kavramsallaştırılması gerektiğini ve neden bu kavramın dışında cep telefonu pratiğinin etkili ve etkin olarak ele alınamayacağı iddiasıyla bitireceğim. Bunu yaparken de, cep telefonu kullanıcılarıyla onların bu makinayla kurdukları ilişkiler hakkında yaptığım röportajlardan kimi örnekler sunacağım.

\section{Anahtar Kelimeler}

\section{Cep telefonu, duygulanım, teknolojik-} alan, habitus

* Bahçeşehir Üniversitesi Illetişim Fakültesi burcelik@yahoo.com

\section{Abstract}

This paper seeks to develop a conceptual understanding for the search of cellular telephony as an artifact, which has become incredibly popular in particular social contexts and also proposes to rethink Appadurai's concept of technoscape. It stresses how relational concepts such as imagination, attachment and emotion define inherent dimensions of social experiences of technoscape. It argues for an analytical sensitivity when considering the technoscape -and its attendant imaginational and emotional experiences -as both a global and a local site for social practices. After providing historical and introductory accounts of key dynamics and issues with regards to 'technologies' in Turkey, I will conclude by demonstrating why the technoscape in Turkey should be conceptualized as an historical dream of presence, outside of which cellular telephony cannot be effectively and affectively thought. By doing this I will also use some of the statements of my informants with whom I conducted interviews about their relationships with cellular telephony in their everyday lives.

\section{Key Words}

Cellular telephone, affectivity, technoscape, habitus 
A technology becomes popular, mainly because it is meaningful and useful. Its meaning and instrumentality are largely shaped through practices of people within certain social, political, and cultural contexts. Thus what transforms a tool into a meaningful technology is its capacity to "respond to or even anticipate our own wishes and capacities" (Sofia, 2000: 187). In what follows, I will attempt to develop an understanding, which aims to situate cellular telephony as a contemporary collective practice of individuals in Turkey within larger historical, social, political and cultural context. I will propose to work with the concept of technoscape, which I believe has the potential to open up an analytical site in which we can comprehend the relations between the local and the global, between the individual body and the social structure. By extending the concept of technoscape into more imaginational, emotional field of experiences, this paper seeks to contextualize cellular telephony as a kind of technological "response" to collective desires, wishes, purposes and imaginations. After providing historical and introductory accounts of key dynamics and issues with regards to "technologies" in Turkey, I will conclude by demonstrating why cellular telephony in Turkey should be investigated through understanding of the technoscape. Certain examples that are drawn from my larger ethnographic research on Turkish cellular telephony including the qualitative interviews with the cell-phone users ${ }^{1}$ in

${ }^{1}$ As a part of my larger project on Turkish cellular telephony, I conducted interviews with 50 cellphone users, with different demographic characteristics who live in Istan-
Turkey will demonstrate why and how we need to rethink the concept of technoscape as a historical dream of presence.

\section{Movement and imagination in the technoscape}

Movement and imagination are two key concepts, describing the promises, potentialities and experiences of the technoscape. Arjun Appadurai (1990) first used the term technoscape, along with other scapes like ethnoscape, finanscape, ideoscape and mediascape, to describe the fluidity of globalization. His account of globalization is based on an argument that something has changed in the world; that "the imagination has become a collective and social fact" as a result of the technological changes over the past century (1990: 5). For him, electronic technologies' mediation of everyday life has turned imagination into global social practice. Following Appadurai, the term now circulates in recent work, ranging from globalization studies and transportation research to urban, media and cultural studies. The landscape is often considered as a kind of technoscape in which movement of bodies and things are largely organized and regulated by technologies and technological configurations (see e.g. Sheller and Urry, 2006). Sheller and Urry (2006) conceptualize contemporary experiences of space as multiple engagements with the technoscape that occur "whenever people ride in a train, make a phone call, read a computer scre-

bul and Ankara in 2007. In these interviews, I asked the cellphone users to analyze their own relationship to the cellphone. 
en, simply step off a pavement to cross a road, or hike one marked trail. Data, pictures and sounds also flow through technoscapes" (8). Importantly, Sheller and Urry (2006) highlight the technoscape's association with specific equipment, how "a car, a mobile phone, a camera, a screen, a hiking boot and so on" can enable a particular production and consumption of space (ibid).

The technoscape refers to both mechanical and informational technologies which facilitate "movement" or "action" that is not limited by the physical deterritorialization of the body. Movement is not restricted to images, data, information but also the virtual and imaginative movement of the body. Through generating new practices in time-space, the technoscape drastically changes traditional understandings of distance and proximity, absence and presence. For instance, by providing the mean of virtual travel, digital technologies have transformed what we think of as closeness, creating a feeling of co-presence while bodies remain physically distant (Licoppe, 2004; Urry, 2000). The whole promise of technoscape derives from its capacity for displacement and circulation.

\section{Attachment and movement in the technoscape}

In the "culture of circulation", as an effect of globalization (Lee and LiPuma, 2002), mobility becomes a sign of liberty and modernity. In an era of globality, bodies become more attached to "movement" as an ideal and as a requirement of the global world (Ahmed, 2004). However, "movement" becomes an ideal on the condition that not all bodies nor all objects and images have an equal relationship to movement. Globality depends on the movement and circulation of some bodies, images and objects and not others (Ahmed, 2004). For those who are able, an attachment to movement becomes a new form of social bonding (ibid). This attachment links one to others, forming a "global community" which consists of the those who can move - virtually and physically - in contrast to others who cannot (see Nussbaum, 1996).

The technoscape, which comprises the means of physical, virtual, and imaginative movement, plays a significant role in this attachment to movement. The quality of the technoscape, the degree of its absence or presence in an era when global cultural forces prevail, marks differences between regions, countries, or even collectives. As Doreen Massey (1993) argues, power geometries play a critical role in the perception of technoscapes, so that space-time relations vary across different geographies. Differentiated mobility is integral to the social construction of space and time in an age when imagination is available to all, but the very experience of movement (virtual and physical) varies among different groups, collectives and nations. As Massey stresses, the issue is not just if one has access to the flow or movement but also how people engage with the means of mobility.

Many recent studies show that in particular regions of the world, the mode of engagement with the technoscape determines the sense of and the feeling about the "landscape" in which people live (see Chakravarty, 2004; Rafael, 2003; Bull, 
2006). Larkin (2004) demonstrates how the use of second-hand videos, as the only possible film-viewing practice in Nigeria, generates among Nigerians the sense that Nigeria lives outside of "history". The inability to adopt technological novelties translates into a collective feeling of resentment. Conversely, the ability to adopt the newest technologies can engender a collective pride, such as in the Philippines (see Rafael, 2003). The technoscape thus opens up a site where different people come to imagine and feel together, yet it also demarcates the very distances between different geographies by inserting new boundaries and barriers. The technoscape connects, attaches one to the other, frames kinship as different people are brought together by the same social practice. However, it also separates one from another on the basis of language differences, class differences, and gender disparities. These diverse issues tell us that the technoscape is not only a collection of materialities that produce collective imaginations but also a plane of affect ${ }^{2}$ where social attachments and detachments affectively take place, where bodies and collectives affectively take shape.

\section{Emotion and imagination: Affectivity of the technoscape}

The issue of the affectivity of the tech-

${ }^{2}$ Here I rely on Grossberg (1990), who wrote, "affect is the plane or mechanism of belonging and identification (of which identity, constructed through either ideological or psychoanalytical interpellations, is only one form)... affect defines a structure and economy of belonging" (84). noscape is critical to a social study of technology, and it can be investigated through different scales ranging from the feeling of the individual body with the technological tool to the regional and national technoscape. When trying to grasp why some technologies are particularly popular, why and how they become objects of collective attachments, and even of addictions, we need to take into account the affective possibilities and experiences of these technologies. For both the individual and the collective, from their physiological to sociological aspects, technologies necessarily speak to the world of emotions, affective relations.

Emotion and affect are generally differentiated in both sociological and philosophical works. While emotions are described as more cognitive experiences of the body, affect refers to non-cognitive, almost unconscious, "irreducibly bodily and autonomic" intensifications (Massumi, 2002: 28). We feel the physiology of being affected and then emotionally respond through the resources of our memory. Emotion then "represents the assemblage of any affect with our previous experience of that affect" (Nathanson, 1996: 13). Affect emerges out of transition (various means of contact) between bodies, between body and space or between body and thing. Affect is contextual, situational, trans-situational (Massumi, 2002), and always involves "potentiality" and "excess" (Anderson, 2006). Being affected and affecting are two aspects of the bodily movement that point to the openness of the body to the other, the world or the object (Massumi 2002; Anderson, 2006; Ahmed, 2004). However, in contrast to emotions, af- 
fect affords a potentiality and an excess which can transcend the boundaries of the social (Anderson, 2006). Affect can shake up the body, may realize the potentialities that are described by bodily intensities and might outrun the cognitive limit of the body. The potentiality and excess of affect is precisely what might threaten the social, political, historical foreclosures that make up the subject or the social body (see Probyn, 2004; Anderson, 2006).

In other words, affectivity resonates with the possibility of being beyond identity, beyond the social closures of the body, beyond collective feelings and shared emotions. The promise of technology exists in direct relationship with the affective possibilities of living in reality. Technologies alter the very basis of our sensory experience and drastically affect what it means to live as embodied human agents (see Hansen, 2004; Hayles, 2002). Experiences with technologies are also grounded in the biological potential of human beings. For instance, the source of virtual reality is not technological, but rather a biologically grounded adaptation to newly acquired technological extensions provided by new media (Hansen, 2004). Yet what is physiological is also psychological and social; the source of meaning in technology is the affective body itself. In his theory of techniques of the body, Marcel Mauss (1979) tells us that the body, "the total man" and his actions need to be understood with a triple consideration instead of a single consideration. This tripartite approach requires one to consider the body as a physiological, psychological and social instrument. In my view, the concepts of affect, feel- ing and emotion, with their physical, psychological and social dimensions, are highly useful to understand how the body relates to the technoscape and to technologies.

Affectivity introduces the power of creativity and possibility into the life worlds of bodies, in contrast to socially constructed structures, ideas, representations and identities. The affectivity of technologies transfers affective "power" from the object to the body (Levy, 1997). Technologies become promises of "exit" and "arrival" by triggering the affective potentialities of the body (see Ronell, 1989). Technology becomes a call for the experience of imagined as it triggers the potentiality of the feeling body that essentially feels out-of-space. Thus, the affectivity of the technoscape is not only bound up in historically and socially shaped emotions and feelings, but also promises to actualize affective potentialities. Although affects are recognized, judged and interpreted according to what we already know, their "potentiality" and "excess" still linger even as technologies organize the bodily practices of everyday life. Thus, the affectivity of technology needs to be studied alongside an historical understanding of technoscape (i.e. how technologies have been imagined, idealized, experienced and sensed in particular society). Perceived and experienced affective potentialities of technology "can only be comprehensible within that specific cultural frame of meaning and style and larger historical frames of power and discipline" (Appadurai, 1990: 148). As Grossberg (1990) puts it, "the same object, with the same meaning, giving the same pleasure is very different in 
different affective contexts. Or perhaps it is more accurate to say that different affective contexts inflect meanings and pleasures in very different ways" (80).

A particular technology or technological artifact becomes localized in social practices by making connections to what is assumed as local. How a particular technology responds to historical imaginations, idealizations, and feelings; what kind of affective potentialities it suggests a body might experience in relation to historically and socially constituted emotions; how it promises to alter the current space-time relations of the collective or of the individual; how it can be used in social struggles, for positioning oneself within social space; and how it connects and separates people are all integral to the process of localizing a global technology. Producing particular performances of technologies involves opening up new possibilities for bodily feelings and feeling for how the local or national technoscape relates to the global technoscape and the "others" that are part of it. Just like any technology, the performance of cellular telephony is mediated and largely determined by the historical imaginations, idealizations and collective feelings. That is to say, a cellular telephone, with its standard features and capabilities is only a thing, a tool or a gadget. The cellular telephone becomes a technology when it is socially and culturally appropriated; as it is affectively domesticated (for countries that do not produce but export it); as it serves collective imaginations, idealizations and dreams; and as it promises an exit from the historically constituted foreclosures that limit the possibilities of the body.
How a technology is used, to what extent it becomes a social practice for collectives, and how it becomes an object of collective attachment or addiction are all determined by social, cultural, affective, economic and political conditions (see Sterne, 2003a). For countries that export technologies, the domestication of a particular technology entails a series of appropriation strategies and techniques that speak to the historical imaginations, collective ideals, dreams and patterns of affective relations and dominant collective feelings. To work on historically contingent organizations of local technoscapes, we need a conceptual approach that reflects the specific cultural, historical, political, and social conditions within which technologies are effectively and affectively domesticated. Jonathan Sterne (2003b) recommends working with Pierre Bourdieu's social theory in order to grasp how history and social structures come into play in transforming a tool into a technology that is socially practiced and produced.

\section{Habitus and social space}

Bourdieu's social theory encourages us to look at how and why the social enters into our bodies. This includes analyzing how and why historical, structural, and objective realities determine the way we think, feel and act, whether we are conscious of what we are doing or not. His concept of habitus designates how social structures are embodied in everyday practice. Habitus refers to understanding bodily practice as one in which social structures (e.g. ideas or representations of abstractions like class and gen- 
der) are incorporated by agents and "delimit how they can move and in which spaces they can move" (Probyn, 2004: 336). The habitus is formed and reformed through interactions with material and social worlds. It is not simply the reproduction of social structures; individuals develop habitus through processes of socialization and classification, and are constantly changing based on their interactions with social structures. Sterne (2003b) suggests that "technologies are subjects of habitus, they are organized forms of movement" (370). Technologies involve embodied social knowledge and the body acts with them (technologies), most of the time by not being distinctly alerted about their presence. Although each technology refers to different bodily practices and social dispositions, technologies are in general integral to the habitus in the sense that they generate practices, are made up by these practices, and become means for positioning oneself in the world.

The habitus refers both to incorporating social structures like a "genetic knowledge," and to the spontaneity which enables agents to operate within social space according to “one's position in a field and one's access to and possession of certain kinds of capital resources" (Sterne, 2003b: 375). Capital is integral for maintaining distinctions between classes, collectives in social space. While economic capital refers to money and property, cultural capital defines cultivated dispositions, such as aesthetic values, academic credentials, and material objects that require specific knowledge to appropriate them materially and symbolically. Closely related to economic and cultural capital, symbolic capital is a means of socially recognized legitimization which "works partly through the control of other people's bodies and belief that is given collectively recognized capacity to act in various ways on deeprooted linguistic and muscular patterns of behavior, either by neutralizing them or reactivating them to function mimetically" (Bourdieu, 1990: 69). Finally, social capital functions to show one's networks of family, friends and contacts. Each form of capital works to establish one's position in social space.

Agents are located in social space "according to their position in statistical distributions based on the two principles of differentiation...economic capital and cultural capital" (Bourdieu, 1990: 6). In other words, social space is where differentiation takes place based on "a set of distinct and coexisting positions which are exterior to one another and which are defined in relation to one another through their mutual exteriority and their relations of proximity, vicinity, or distance as well as through relations of order, such as above, below and between" (ibid). The main idea of being in social space is to be different from others. The position one occupies, by possessing different kinds of capital, is integral to the struggles to conserve or transform representations of social space (ibid, 12). Crucially, while social structure regulates position, one's position is not fixed; there is always room for spontaneity, improvisation and creative social action. Yet, spontaneity and improvisation are bounded by cultural memory, by history. Potentialities are inscribed in dispositional relationships, ones of body and of situations 
(Sterne, 2003b). The struggle to realize the potentialities and exceed the historical boundaries is what gives character to social space and practice.

Technologies occupy a significant place in social positioning and struggle. Sterne writes "a technology is always at any given moment, socially located. It is always implicated in social struggle" (2003b: 383). As embodied practices and also as possessions, technologies may serve to distinguish one group from another and to produce commonalities between different people or groups in the same social space. A technology may well function as cultural and symbolic capital, becoming a form of agency, prestige and control. Bourdieu's conception of habitus - capital and taste - is essentially based on categorizations of different classes, groups or collectives. The question of how technology comes into play in the social struggle of different groups can only be answered by looking at how particular performances are organized through technologies, and to their basis in historical embodied knowledge, collective feelings and emotions. To understand the particular habitus in relation to a particular technology, we need to take into consideration how imaginations and idealizations, embedded in historical knowledge and belief that affect the technological practices. Now, I will try to provide historical accounts of the key dynamics and issues that have been effective in shaping the perception, imagination and experience of technologies in Turkey.

\section{The Technoscape in Turkey}

Since Turkey first started dreaming of modernity, notions of technology have been integral. The Turkish Republic was founded in the early 1900s with the aim of instituting a modern and secular nation-state. Some authors in Turkey argue that the might of modernity was first recognized by the Ottoman rulers and elites through interaction with technologies and techniques of the Europeans (see Tekelioğlu, 1996; Ahıska, 2005). However, while there are numerous studies of Turkish modernity, only a few focus on technology. Thus our historical analysis of the technoscape in Turkey is tied to a search for hints that can reveal how the technoscape was envisioned in Turkey throughout its modern history. One area that opens up a relatively rich site to grasp how the early technoscape was imagined and experienced on daily level during the transition from Ottoman to Turkish Republic is canonic Turkish literature (including the works of Ahmet Hamdi Tanpinar's Saatleri Ayarlama Enstitüsü, Recaizade Mahmud Ekrem's Araba Sevdas1 etc). Before providing an introductory account of "technology" in Turkish literature through the writings of literary critics, we shall talk a bit about the social, political, economic structure of the transition period which becomes evident in the collective feeling of people at the time as it is insightfully described by Orhan Pamuk.

Orhan Pamuk who won the 2006 Nobel Prize in literature often describes the feeling of this landscape as melancholia. Pamuk (2003) writes that the founding of the new country, the "Turkish Republic", often seems to him as show- 
ing desire to get rid of the saddening memory of the objects that are mindful of the empire being lost rather than of the joyful desire for modernization. He writes that rather than mourning for the loss of the empire, this new construct called "Turkey" simply rejected the empire (and rejected its loss) but could not escape from its remains, which is manifested in everyday life in the shared melancholia of early Turkish citizens. The national technoscape was one of the sites that people of Turkey, especially urban dwellers, have felt the intensity of melancholia which came to the fore as the "feeling of defeat and loss" and "the pain of poverty".

In the transition period from the empire to the modern republican nation-state, encounters with technologies involved interacting with the western power. In the late Ottoman period, large cities were filled with post offices. Those that were working properly, enabling safe and fast communication, were the European ones in the Ottoman territory, while the Ottoman postal system was disorganized and slow; one of the first things the new republic modernized was the postal system. Reforming and modernizing the "backward" Ottoman technoscape has been one of the main ideals and accomplishments of the new country. For "technology" has always been the twin sister of modernity, progress, and development in the national imaginary.

In that respect, the technoscape in Turkey has been shaped as a sort of messianic plane which has been imagined to transform the landscape, to bring the spatio-temporal movement (progress to- ward modernity), and to make the nation "catch up with the western civilization" (the motto of modern Turkey since it was founded). The technoscape in Turkey can be approached as a "dream of presence" which defines a process of imagining that engenders becoming. However, the technoscape as a dream of presence is also "real" in that it binds "various inclinations, sensations, and responses into particular imaginations of presence" (Rose, 2006: 545). For Turkey, the technoscape as a dream of presence imbricates a connection between self and other, body and collective, body and world, and local and global. The technoscape is a "performative and emotive" (see Reddy, 2001) dream of presence which provides infrastructures, communication pathways, narratives and stories to orient and inspire becoming for a collective as well as for an individual. As an historical dream of presence, the technoscape has performed its task in Turkey, of accommodating the landscape's presumed "lack". The gap between the Ottoman and European technoscape "marked" the time-lag between the east and west, for the technoscape has historically been a site that "shows" temporal differences between the two. As such, it has also been a site of valuable investments, economically and affectively. The technoscape has always been both the source and the means of overcoming melancholia. Not only has the technoscape been crucial in terms of "showing" the irrecoverable distance between the east and the west, now the local and the global, but it has also played a key role in Turkey in demarcating elitists and the "people", Islamists and secularists. In short, the technoscape has always been crucial to the political, 
the cultural and the social in Turkey. As Ronnel (1989) suggests, technology has ruled - and continues to rule - the power (81).

Jale Parla (2003), a renowned literary critic, suggests that Turkish novelists have been preoccupied with cars (along with other vehicles such as carriages, buses and tractors) from the very beginning, which fostered a subgenre of car novels. ${ }^{3}$ Parla argues that in all these car novels, the vehicle appears as trope rather than as a means for transportation (2003: 535). She writes, "the trope of car becomes important at least two ways: in its relationship to the machine and in its signification of a particular kind of space that has become meaningful in Turkish modernization” (ibid). Nurdan Gürbilek (2003) suggests that the car in these novels is "the symbol of not only changing places but also changing identities. It represents the promise of a second life, the effort of being someone other than one's inadequate self, to imagine and show oneself as the other, the attempt to close the distance between" the east and the west, the local and Europe (613).

Technology was a strange land in the social imaginary because it was imagined and experienced as such. Its imagined social and historical alienness mediated the very bodily practice of technologies, so that hesitancy, anxiety and fear characterized bodily relationships to tech-

\footnotetext{
3 Among the novels, Parla examines, there are: Araba Sevdası by Recaizade Mahmut Ekrem, Sarı Traktör by Talip Apaydin, Fikrimin Ince Gülü by Adalet Ağaoğlu; Sevgili Arsız Ölüm by Latife Tekin, Mach I'dan Mektuplar by Sevim Burak.
}

nologies for a long time. For instance, household appliances, such as pressure cookers, washing machines, vacuum cleaners, and water heaters were appealing both as symbols of modern domestic spheres and for the speed and comfort they brought to domestic life, yet they also spread anxiety and fear. Pressure cookers and water heaters were used as home mains in Turkey. Murathan Mungan, a well-known Turkish poet, writes, "we were so used to hear the news of explosions of pressure cookers during my childhood" (2000). Once people became familiar with using pressure cookers and water heaters, those that ran on gas started to explode and kill family members. In addition, Turkey has always been a land of frequent traffic accidents, killing of hundreds of people every year. Mungan argues that because we used to feel so alien even to these "user friendly technologies", we could become clumsy, panicky and silly very easily. Things that were supposed to ease life were actually taking lives due to user faults. All of these incidents - traffic accidents, exploding pressure cookers and water heaters were actually intensifying the historical belief that the technoscape is a foreign territory, of which we want to be part, and yet pushes us back to where we were (see Mungan, 2000).

Although Turkey adopted many technologies almost simultaneously with Europe, the feeling of being late to the land of technology has never left its landscape. This sense of belatedness also draws upon desires, aspirations and fears, envies and resentments (Gürbilek, 2003). Perhaps motivated by the fear and anxiety of being latecomers, and by a "guilt" 
inherited from the lost past, any adoptable technology has entered some people's lives at high speed. While technologies were fascinating to all, their actual uses were limited to a small segment of society for so long. On the one hand, in the social imaginary, which is fueled by the historical imaginations, idealizations and collective feelings, technology has been the name of the western civilization and modernity. On the other hand, its use in the national territory has historically been limited to a certain segment, which differs from others through their financial capabilities (economic capital), through their educational qualifications (cultural capital) and through their hegemonical power over others (symbolic capital). In other words, the use of western technologies has historically been limited with elites, rulers and wealthy segment of Turkey.

Roughly starting from the 80 s, as the structure of social space has altered due to the internal migrations from rural areas to big cities, due to the newly adopted liberal market economy system, and due to the fact that consumption has become a new drug for masses, the use of technologies has spread to different classes including the new comers of the urban spaces, periphery, or "people". The motto of the 1980s, "Turkey is opening to the world," was implying the role of technologies in this ambition. Turkey was becoming another country, shifting from an inwardto an outward-looking social structure. The strict modernization and secularization policies of the state have partly dissolved due to the new state policy of "opening to the world". The organization of a national technoscape was seen as crucial for achieving the dream of making Turkey a body that could communicate and be compatible with its western counterparts. "Highways are liberty", announced Turgut Özal, the prime minister at the time, who initiated the liberal market economy and started the privatization of state institutions. ${ }^{4} \mathrm{He}$ promised new highways, a high penetration rate of telephone lines and electricity, and water to areas that have always been economically and socially marginalized (the Kurdish districts especially). Transforming the technoscape was a necessary part of imagining and idealizing a civilized, modernized and unified Turkey. However, transforming the technoscape simply meant commodifying the means of engagement with technologies.

Where the state was unable to unify, mobilize and modernize the country, commodification would do the job. Commodified spaces and practices were there to open up sites where bodies could do things, could move in opposition to the cultural policies of the state. The commodified technoscape started to run counter to the state technoscape. As radio was the voice of the state's strict modernizing policies, commodified sound technologies enabled alternative social practices of listening (see Özbek, 1997). While state-run television was a medium of pedagogical state-power, video technologies provided entertainment. While telephone technology was

${ }^{4}$ Turgut Özal's statement was highlighted in a newspaper advertisement in an exhibition entitles "Lifestyles of Turkey from the 80s to 2000s" which was organized by Meltem Ahıska, Zafer Yenal and Bülent Erkmen in sponsorship of Osmanlı Bankası in 2005. 
restricted to the privileged, wireless emerged to integrate the scattered agents of the periphery. In opposition to the state-run technoscape, the commodified technoscape was pointing to the possibility of intimate experiences between the social body and technology.

These commodified technologies shaped sites where the "people" can speak as well as hear themselves. Not only did they open up a possibility for migrants, the poor, children, youth, or any 'other' (such as Islamists -the political Islam has become apparent in the political landscape after the 80 s through communication technologies) in society, but they also engendered new social practices in which urbanized, middle-class people found ways to express and recognize their own "others" which have been repressed under the strict modernization policies of the state (Gürbilek, 2001). Video technologies, music listening technologies, and television, among other technologies, concomitantly produced distinct social practices for different individuals that familiarized "technologies" with "culture", with what is assumed as our own. These technologies were imagined and inserted in social practices of everyday life which helped to make all others recognizable, acceptable and even loveable both by themselves and by others. By using the power and authority of technology, things could become more decipherable for social body. Appropriating technologies for the production of "local" has worked to make "local" or "what is our own" acceptable to show.

Recognition of the other did not occur peacefully in social space. For instance, while "friends of wireless" be- came a collective through their exclusion from the state-run telecommunications technoscape, wireless also came to define a certain class' taste and habitus which was degraded and considered as backward by elitists. Technological practices have always been integral to social struggle. More importantly, social practices of technologies in Turkey trigger the historically embodied desire to "express" or to "show" what we, as people of Turkey, are lacking. The technological habitus of "people of Turkey" has come to reflect and reproduce a Turkey imagined as in between the east and the west, with a disgraced image of "homelessness", the landscape where a collective inferiority complex prevails.

Journalistic representations of cellular telephony continue to reproduce a degrading attitude towards the so-called periphery's habitus. One newspaper column states that technology functions as a mirror in which we can see ourselves objectively, and our people's use of cellular telephony shows what we lack compared to any western country; in essence we are ignorant (Berberoğlu, Hürriyet, 06/02/99). According to this common understanding, not only do we lack the scientific reason to produce technology, but we also lack the very knowledge to use technologies properly. Yet paradoxically the technoscape remains the force that will transform lived Turkey into the landscape of imagined Turkey. 


\section{Cellular telephony: The popular performance of the contemporary technoscape}

"I think if there is a nation that would never detach from cellular telephones, it is Turks. Perhaps we should change our motto from "horse, woman, weapon"

to "horse, woman, weapon and cellular telephone"

(M. Ali Yilmaz, Milliyet, 2004)

When the cellular telephone was first introduced in 1994, it was defined as a personal technology. Above, I have tried to designate that "technology" is a sort of messianic word for melancholic bodies in Turkey. Therefore it was implausible that the people of Turkey would be indifferent to a personal, purchasable technology. A technology that would not only connect a Turkish body to a global -western- community but also would possibly transform one's position in the social space and give the affective and imaginational experience of bodily movement and social connection to its users when departure from the landscape of Turkey has been one of the collective desires and the dream of mythic unity of nation has been one of the impossible dreams of the collective. Moreover, a technology which is "user friendly" not only in the sense that its use is simple and functional, but also in the sense that it allows one to upload one's narrative (that is desired to be told both to oneself and to others) in its containing virtual space (see Sofia's analysis on containing technologies).

Cellular telephony offers more than a display of one's desired social status and lifestyle; it articulates and reflects the visions of self and individual identity by promising a certain sociality as well. Social status, lifestyle, economicsocial-cultural capital are all integral to individual identity and to cellular telephony's meaning for the self. One of my informants told me, "it contains all of my memories, my photos, messages, telephone numbers of my friends...it is like me... one can tell what kind of person I am by looking at inside of my cell..." (E). Despite rigid budgets, many people in Turkey purchase this object and renew it whenever they can, making both economic and affective investments. Understanding the extent of users' desire for cellular telephones might help us to grasp the intensity of this attachment. Cellular telephony has come to Turkey, when Turkey experienced one of the major economic crises in its history (1994). Most of my informants told me that they have purchased their cellphones with credit cards by dividing the fee into payable installments. Today, it is no more a luxurious item but a ubiquitous object that half of the population owns. Today, half of Turkey's population of Turkey owns a cellular telephone and many express that they feel lacking something as if they miss something essential to their bodies. "If I don't have my cellular with me, I feel empty. I can lose my lover, but I don't want to lose my cell. My cellular is my everything!"' says a street perfume seller in Istanbul.

Today, cellular telephony in Turkey is not only associated with life - as a technology which connects one to life-

${ }^{5}$ Radikal. February. 24. 2007. p. 3. Taken from a published interview with a street perfume seller in Istanbul in Radikal. 
but it is also imagined and experienced as an affective and instrumental protector of its users from diverse risks of the city life. Although most of the time, one is consciously aware of the fact that the cellular telephone might not work when one desperately needs its connection, or that using the cellular telephone might be too late in the face of any possible threat, feeling of a cellular telephone in one's hand or close to the body still gives this sense that one is safe. It is an affective and psychic protector, a talisman with which one feels secure, still connected even when alone and vulnerable to the hazards of the city.

The cellular telephone has become the "national organ" in Turkey when the social space is extremely fragmented into enclaves of different identity politics such as Kurdish nationalists, Turkish nationalists, Islamists and Secularists. Just as cellular telephony functions in a way to differ one body from another in the social space, so too its work can be interpreted as a performance as well, one that becomes meaningful insofar as it promises a certain sameness or commonality between different collectives. An engagement with cellular telephony is also a social practice through which these diverse, polarized groups can form and display certain social bonds. Vicente Rafael (2003) invites us to think of cellular telephone politics as a messianic dis-

${ }^{6}$ Mehmet Ali Yilmaz, a columnist in Milliyet, wrote that the cellular telephone has become a national organ of Turkish society (published on 24 February, 2004). See also Zülfü Livaneli's 2005 novel, Leyla'nın Evi, where he calls the cellular telephone as the third ear of Turkish bodies. course replete with promises of justice, commonnalities, an integrated collective and a crowd of equal people. Many authors have conceptualized communication technologies as social instruments that can integrate a large collective, like a nation or society. For instance, Avital Ronell writes for the telephone, "The telephone connects where there has been little or no relation, it globalizes and unifies, suturing a country like a wound" (1989: 8). In a similar vein, we can surmise that the cellular telephone as a "connecting" medium has become an object of collective attachment in contemporary Turkey where the means of relations with "others" are largely precluded.

Cellular telephony as a technology which promises experiences of movement -virtual, imaginative and physical- has become an object of collective attachment when people of Turkey, especially youth, dream to migrate to another country which is far from the territory of Turkey. The cellular telephone as a "portable", "pedestrian" and "personal” technology (Okabe, et. al. 2005) gives the sensation, imagination and affective experience of movement to the individual bodies. The cellular telephone pervades the distinction between spaces -the spatial difference between indoor and outdoor, the spatial experience of being on the street and being in the space of transportation vehicle, between familiar and unfamiliar spaces. It is immersive -it takes the body in it, holds the body during its connection, opening up an exteriority, a certain exit from where the body is. The cellular telephone generates a hybrid space that merges physical and digital spaces that immerses the body by 
excluding the surroundings (Plant, 2000). Adriana de Souza e Silva writes, "most of all immersion depends on imagination" (2006: 30). The user of the cellular telephone as s/he connects with it to the other, s/he immerses into the hybrid space of cellular telephone where imaginational movement, exit, exteriority is possible. Asuman Suner (2001) searched for an answer to the question of "why in a country where the income per capita is very low compared to other OECD countries, the cellular telephone has become popular as it is in some European countries?" Rather than look to more traditional formulations of social status or modern lifestyle, she suggests that it is perhaps because the cellular telephone gives its owners a feeling of movement, departure, or migration to another time and space. She writes that in a landscape where the majority of young people dream to leave Turkey for somewhere else, the cellular telephone's associations -as a global, mobile technology- of mobility, liberty, and freedom speak to the imagination and virtual experience of departure.

As a global technology that is produced and invented somewhere else cellular technology is a foreign technology. When cellular telephony is recognized as part of the global network whose felt and perceived center is not Turkey, it continues to foster historical resentment, anger, or melancholia. As one of my male informants says, "I regret that we couldn't invent such a thing" and the reason is that "we lack the self-confidence". Cellular telephony shows what "we lack" insofar as it allows for varieties in its use, in shape, in its performance. Yet at times the imag- ined Turkish stamp on global cellular telephony represents what differs Turkish cellular telephony from others as an ability to creatively adapt the technology. One humorous television advertisement for Akbank banks is an exemplary reflection of how cellular telephony is envisioned as marking an imagined difference between the local and the global.

On a fast train, an American, a Japanese, and a Turkish guy sit a table, having their lunch. The American with a cowboy hat shows off his cellular telephone and expresses his pride at having invented this technology. The Japanese fellow, who has a flying cellular, says that he is proud of developing and improving this technology. The Turkish guy, who wants to end the discussion with his display, says that he will pay for their lunch - he removes his cellular from his pocket, contacts his bank, takes out a loan (apparently, a lunch on that Turkish fast train is prohibitively expensive) and pays the bill immediately. He declares that he is proud of inventing new ways to efficiently use this technology. In the end, both his American and the Japanese friends accept that the Turkish invention is the greatest. The Turkish guy recommends that in their own countries they work harder to catch up with Turkish inventions.

We can read this ad as a result of an unsuccessful advertising strategy which could not predict its own reception, as the ad implies that Turkish difference, stamp would appear when it came to finding new ways to take bank loans. Yet even as a poor ad, it represents core aspects of my previous discussions of the technoscape, melancholia, and the ways 
in which cellular telephony is seen as a means to overcome the historical melancholia in the social imaginary. This ad illustrates how as a contemporary performance of the historical dream of presence, cellular telephony opens up a site where the gap between the local and the global is imagined and accommodated. Historical melancholia and the historically imagined western gaze pervade the commercial, contributing to the popular perception that cellular telephony can only become a means of national pride when it garners the approval of the imagined western gaze -in this case the imagined global gaze of the global community. Locality becomes meaningful insofar as cellular telephony can link Turkey to the global network in ways that allow for Turkish national pride to enter the sphere of globality, a vision that we have long dreamt.

\section{Conclusion}

The technoscape as a multilayered concept can open up a rich domain through which we can contextualize the potential material functioning and meanings of the cellular telephone within particular historical and socio-technical imaginations and idealizations. In that respect, I have tried to designate that what transforms cellular telephony from being a tool into a technology is not merely its instrumental work and potential meanings as majority of researches on cellular telephony suggest. Rather it is precisely the social, historical, cultural conditions, including the collective imaginations, feelings and idealizations that give rise to popularity of cellular telephony in Turkey. When the cellular telephone is understood as one of the performances of the technoscape that promises certain affectivity to bodies through which different experiences of movement and connection are possible, its popularity in particular socio-technical contexts where the means of bodily movement and social connection lack might be more fairly examined. Cellular telephony, as a performance of the technoscape, "gathers" when relation, connection between the different collectives, and individuals do not seem very possible. It becomes a part of the historical dream of presence in the form of unity of a nation, when the "nation" feels fragmented, divided, has lost the ability to connect. In a similar manner, the technoscape becomes a consolidation for melancholia where melancholia emerges out of an affectation with the landscape that is positioned as non-west, as "outside" of global community -be it European Union or larger western community.

\section{References}

Ahıska, M (2005), Radyonun Sihirli Kapısı: Garbiyatçılık ve Politik Öznellik, İstanbul: Metis.

Ahmed, S (2004), "Collective Feelings: Or, the Impressions Left by Others", Theory, Culture and Society, Vol. 21 (2).

Appadurai, A (1990) "Disjuncture and difference in the global cultural economy", in M Featherstone (ed.), Global culture: Nationalism, globalization and modernity, London: Sage.

Anderson, B. (2006) "Becoming and be- 
ing hopeful: towards a theory of affect", Environment and Planning D: Society and Space, vol. 24(5).

Bourdieu, P (1990), The Logic of Practice, Oxford: Polity.

Bull, M. (2004) "Sound Connections: an aural epistemology of proximity and distance in urban culture", Environment and Planning D: Society and Space, Vol. 22.

Chakravarty, P (2004) “Telecom, national development and the Indian State: a postcolonial critique" in Media, Culture and Society, Vol 26 (2).

De Souza e Silva, A (2006) "Interfaces of Hybrid Spaces" in A. Kavoori and N, Arceneaux (eds) The Cell Phone Reader: Essays in Social Transformation, New York: Peter Land, 2006.

Grossberg, L (1990) We Gotta Get Out of This Place: Popular Conservatism and Postmodern Culture, New York: Routledge.

Gürbilek, N (2003) "Dandies and Originals: Authenticity, Belatedness, and the Turkish Novel", The South Atlantic Quarterly, Vol. 102(2/3).

İstanbul: Metis

(2001) ) Kötü Çocuk Türk,

Hansen, M (2004) "The Time of Affect, or Bearing Witness to Life" in Critical Inquiry, Vol. 30.

Hayles, K (2002) "Flesh and Metal: Reconfiguring the Mindbody in Virtual Environments", Configurations, Vol. 10.

Larkin, B (2004) "Degraded Images, Distorted Sounds:Nigerian Video and the Infrastructure of Piracy" in Public Culture, 16(2).
Lee and LiPuma (2002) "Cultures of Circulation: The Imaginations of Modernity” in Public Culture, 14(1).

Levy, P (1997) Collective Intelligence: Toward an Anthropology of Cyberspace, trans. $R$.

Bononno. New York: Plenum.

Licoppe, C (2004) “' 'Connected' presence: the emergence of a new repertoire for managing social relationships in a changing communication technoscape" in Environment and Planning D: Society and Space, vol. 22.

Ling, R. (2004) The Mobile Connection: The Cell Phone's Impact on Society, Boston: Morgan Kauffmann.

Livaneli, Z (2007), Leyla'nin Evi, Istanbul: Remzi.

Massey, D (1993) "Power Geometry and a Progressive Sense of Place". in T. Bird, B. Curtis, T Putnam and G Robertson (eds) Mapping the Futures: Local Culture, Global Change. London: Routledge.

Massumi, B. (2002) Parables for the Virtual: Movement, Affect, Sensation, Durham: Duke University Press.

Mauss, M. (1979) Sociology and Psychology, trans. B Brewster, London: Routledge.

Mungan, M. (2000) Teknoloji ve Ideoloji, Radikal Iki, 04. 06. 2000.

Nathanson, D. L. (ed.) (1996) Knowing Feeling: Affect, Script and Psychotherapy, New York: Norton.

Nussbaum, M. (1996) "Patriotism and Cosmopolitanism" in M Nussbaum For the Love of Country: Debating the Limits of Patriotism, Boston: Beacon Press. 
Okabe, M., Ito D., Matsuda, M. (eds) (2005) Personal, Portable Pedestrian: Mobile Phones in Japanese Life, MIT Press.

Özbek, M. (1997) “Arabesk Culture: A Case of Modernization and Popular Identity" in R. Kasaba and S. Bozdoğan (eds) Rethinking Modernity and National Identity in Turkey, London: University of Washington Press.

Pamuk, O. (2003), Istanbul: Hatıralar ve Şehir, Istanbul: Iletişim.

Parla, J. (2003) "Car Narratives: A Subgenre in Turkish Novel Writing” in The South Atlantic Quarterly, 102 (2-3), Summer.

Plant, S (2000) "On the Mobile: The Effect of Mobile Telephones on Social and Individual Life" [http://www.motorola.com/mot/documents/0,1028, 333, 00.pdf].

Probyn, E. (2004) "Everyday Shame", Cultural Studies, Vol. 18 (2/3).

Rafael, V (2003) “The Cell Phone and the Crowd: Messianic Politics in the Contemporary Philippines" in Public Culture, 15(3).

Reddy, W, M, (2001) The Navigation of Feeling: A Framework for the History of Emotion, Cambridge: Cambridge University Press.

Ronell, A (1989), The Telephone Book: Technology, Schizophrenia, Electric Speech, Nebraska: University of Nebraska Press.
Rose, M (2006) Gathering 'dreams of presence': a project for the cultural landscape" in Environment and Planning D: Society and Space, vol. 24.

Sheller, M and Urry, J (2006) "Introduction: Mobile Cities, Urban Mobilities" in M, Sheller and J, Urry (eds) Mobile Technologies of the City, New York: Routledge.

Sofia, Z (2000) "Container Technologies”, Hypatia, Vol. 15(2).

Sterne, J (2003a) The Audible Past: Cultural Origins of Sound Reproduction, Durham: Duke University Press.

(2003b) "Bourdieu, Technique and Technology", Cultural Studies, Vol. $17(3 / 4)$.

Suner, A (2001) "Bir Bağlantı Koparma Aracı Olarak Türkiye'de Cep Telefonu”, Toplum ve Bilim, Vol. 90.

Tekelioğlu, O. (1996) "The Rise of a Spontaneous Synthesis: The Historical Background of Turkish Popular Music" in Turkey: identity, democracy, politics ed by $\mathrm{S}$ Kedourie, London: Frank Cass\&Co.

Verbeek, P. P. (2005) What Things Do: Philosophical Reflections on Technology, Agency, and Design, Penn State: Penn State Press.

Winner, L. (1993) "Artifact/Ideas and Political Culture" in A. Teich (ed) Technology and the Future, New York: St. Martin Press. 